\title{
Some Hil·lûfîm Ben Asher/Ben Naftali in the Manuscript M1
}

\author{
M. ${ }^{a}$ Teresa Ortega MonASTERIO \\ CSIC, Madrid
}

\section{INTRODUCTION}

The manuscript M1 (Madrid, Complutensian University Library) is being studied by the Hebrew Bible Team at the Instituto de Filología of the CSIC. We are preparing now the edition of the masorah of the Pentateuch. This manuscript has been considered one of the codices which served as basis for the Hebrew text of the Complutensian Polyglot edited by Ximenez de Cisneros between 1514 and 1517.

Besides the Masorah Magna written in the upper and lower margins of the text, some long masoretic appendices, which were too long for the margins, are given at the end of several divisions of the Bible. They are written in three columns of 32 lines each. The first one is an appendix to the Pentatench and occupies fols. $81 \mathrm{a}$, third column, to $83 \mathrm{a}$, and contains the following masoretic lists:

1) A register giving the total sum of the parašiyyôt $\underline{\text {, verses, }}$ the middle verse, the words, middle word, letters and middle letter of each book of the Pentateuch. In the last page of Genesis, the number of times which patah occurs with the pausal accent 'atnah and sôf pasûq also appears.

2) The number of hilllufim BA/BN in each book of the Pentateuch.

3) A complete list of the summaries to each of the parasiyyôt $\underline{t}$ giving the sĕdarîm, pěsaqîm, words, letters, hilllâfîm, and others. 
Other appendices are: a list of variations between madin$h a^{\prime} e^{\prime} / a^{\prime} a r b a^{\prime} e$ in the book of Kings, given at the end of the Former Prophets (which is no more in the manuscript); the variations in the number of letters in several of the parasiyyot $\underline{t}$ at the end of the Latter Prophets, and a final list at the end of Chronicles containing more than eigthy lists, including extraordinary points, lists of qürê/kettîb, plene and defective spellings, and others.

The manuscript M1 was studied by my colleague Dr. Fernández Tejero years ago, but the masorah and these appendices have never been published. In this paper, I will analyze part of the lists, those notices concerning the hilllûfîm Ben Asher / Ben Naphtali in the books of Genesis and Exodus. In the future, I plan to analyze these lists in the rest of the Pentateuch. In these two books, I have recorded as many as 110 cases ${ }^{1}$.

At the end of Deuteronomy, in page 81a of the manuscript, in the third column, it reads:

פלגתות שבין בן אשר ובן נפתלי ספר בראשית חמשים ושלוש פלוגתות ספר ספרים

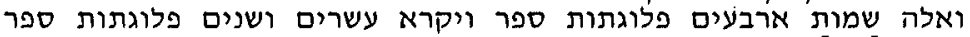
וידמר [sic] חמשים ושלושת משנה תורה ארבעים ושלוש פלוגתות ...

The next page (81b) starts with commentaries about the parašah בראשית, and gives different notices divided in parašiyyôt.

I have selected the cases of hil.lûfim BA/BN of the appendix, and found 40 cases in Genesis and 22 in Exodus. On the one side, many of them are also recorded in the margins of the text of M1, but some others are specific of these lists. On the other side, some cases are recorded in the margins of the text giving the readings $\mathrm{BA} / \mathrm{BN}$, but are not recorded in the lists. In total, we have 70 cases in Genesis and 40 in Exodus. The note of the appendix says that there are 53 hil.lufim in Genesis and 40 in Exodus. In the second case, it agrees with my computing.

As I have just mentioned, all these cases can be classified in three groups:

\footnotetext{
${ }^{1}$ For this study, I have used the lists of the Lipschütz, Mishael ben Uzziel's Treatise on the Differences Between.Ben Asher and Ben Naphtali, Textus 2 (1962) pp. J- $\aleph$, and F. PÉrez CASTro and M. J. de AzCÁrRaga, The Edition of the Kitab al-Khilaf of Misael Ben Uzziel, in In Memoriam Paul Kahle (Berlin 1968).
} 
1) Words quoted in the appendix but not in the margins of the text of M1 (18 cases in Genesis, 9 in Exodus).

2) Words quoted in the margins of M1 but not in the appendix (30 cases in Genesis, 15 in Exodus).

3) Words quoted in both instances ( 22 cases in Genesis, 10 in Exodus).

I have compared every case identified in the lists with the text of M1 in the corresponding passage. The appendix does not give the specific reading of BA or BN, it simply quotes the word, and in some cases, with some vocalization or ga $y a a^{\prime}$. The text itself only says that there is a hîl $\cdot l \hat{u} f$, and in some cases, with some vocalization or $g a a^{\prime} y a^{\prime}$. The text itself only says that there is a hîlllûf in the passage. For instance, in page $81 \mathrm{~b}$ it reads: ... ובלא חלוף [Gen 3,3] וחלופים אשר בתוך הגן.

In this case, M1 indicates the accents, but this is not always like this. Examples of other cases where it vocalizes a consonant or writes the ga 'ya' are found in Gen 7,4 (את-כל היקום), Gen 25,32 (כילמה־זה לי) (כתה) or Gen 26,22), but in these cases the manuscript does not give both readings.

In order to know the exact differences between BA and BN, we have to find them in the cases where both readings are written in the margins of the text. There are 52 of these cases in the book of Genesis and 25 in Exodus. We have to take into account that there is a lacuna from $E x \quad 9,33$ to 24,7 in M1. Some of these cases are not recorded in the appendix (30 in Genesis and 15 in Exodus). In three of them, Ex 2,17, 3,8 and 9,31 in the appendix, it is specified that the passage has no $h \hat{\imath} l \cdot l \hat{u} f$, as follows:

$$
\begin{aligned}
& \text { 2,.. ובלא חילוף ניְגְרְשום ... }
\end{aligned}
$$

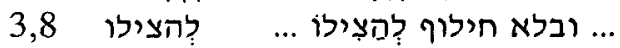

$$
\begin{aligned}
& \text { 9,... 9, 9 }
\end{aligned}
$$

The usual way to indicate that a passage has no hîlllâf is to introduce the words with the note ובלא חילוף, and add the passage with its vocalization. Sometimes, the scribe insists on the exact place where there is no difference. In Gen 24,11, it is written: לִעת צאת הֶשֶׁבות בלא געיה (in the ה). 


\section{INTERNAL CONCORDANCE}

From the comparison of the notes of the appendix with the text of the manuscript and the marginal readings $B A / B N$, I affirm that the internal concordance of the manuscript is very high. In Genesis, both texts differ in only five of the 20 cases studied with a note $\mathrm{BA} / \mathrm{BN}$ and whose passages are also recorded in the appendix.

For instance, the word 2 of the expression 23,4) appears without $g a a^{\prime} y a^{\prime}$ in the appendix, and with $g a a^{\prime} y a^{\prime}$ in the text. This last reading agrees with BN. A similar case

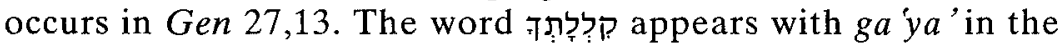
$q \hat{o} f$ in the appendix, and without ga ya' in the text, according this time with BA reading. The other cases are Gen 42,21

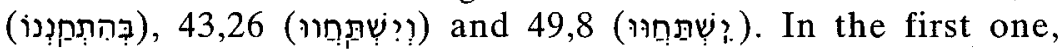
the MP says: ל ופלוגתא דבן אשר. In the other 15 cases, the text is identical with that of the appendix.

In some cases, the readings given in the margins of the text disagree with Ben Uzziel's. Out of the 40 cases of Genesis recorded in the appendix, there are six passages where M1 is contrary to Ben Uzziel, and gives a different hîll lûf: 30,16 (מן),

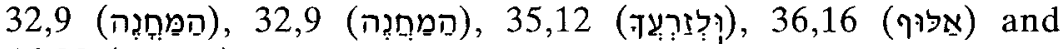

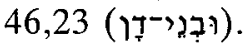

In the case of Exodus, 13 of the 25 cases registered in the appendix are also registered in the margins of the text. We must remember that there is a gap in the manuscript. Only in four of these 13 cases, the text of the appendix disagrees with

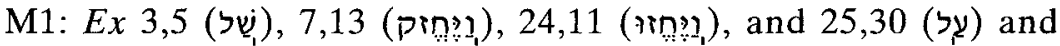
the hîl'lûf always refers to the ga ya'. In the other 9 cases, the text of M1 is identical to the text of the appendix. In one case,

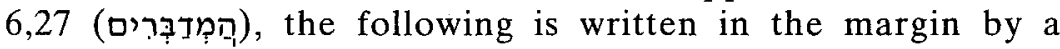
different hand: חטוף בלי פלוגתא דבן אשר ובן נפתלי ובמסור אחרה המדבר. In all these cases, the hîlllûf BA/BN is identical in M1 and in Ben Uzziel.

Two mistakes of differences $\mathrm{BA} / \mathrm{BN}$ are found in the margins of the text of Exodus. The first one is in 33,5. Concerning the

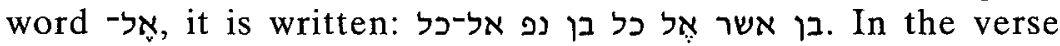
33,5 אל כל does not appear. It may have been confused with 35,4. This hîll-lûf appears in Ben Hayyim's lists. The second one is in 38,30 . Concerning ואת כל, it is written: בן אשר את כל 
ואת כל In 38,30, only apears. It may have been confused with 38,3 , where את כל כלי כל appears. This case is also quoted in Ben Hayyim and in the appendix.

\section{M1 HIL LUFIM AND OTHER SOURCES}

After having verified the internal concordance of the manuscript, I will analyze its similarities with other sources. I have compared it with two very well known works which frequently refer to Spanish manuscripts. These are Menahem de Lonzano's 'Ôr Tôrah and Norzi's Minhat Šay. Both works very often quote notes about hilllûfim or readings BA/BN. They do not always give both readings exactly, but only one of them, and sometimes they deal with Spanish codices and how they should be written.

In the 'Or Tôrah, we cannot find much support. From all the cases of hilllûfîm quoted in M1 in Genesis and Exodus, only seven give some notice, and they are placed in Genesis. In two cases, the opinion refers to words contained only in the appendix, and does not specify the exact difference between the two schools. For instance, in Gen 22,8, concerning the word הก??, Lonzano writes: "without $g a a^{\prime} a^{\prime}$ ». In two cases, he refers to the Sifrê Sefarad: first, in Gen 39,6, concerning the word יפה, he says: "פה with maqqef, not with ma arîk in Sifrê Sefarad"; second, in Gen 38,9, referring to the words is he notes «ל with dages in Sifrê Sefarad». In the first case, the reading agrees with $\mathrm{BA}$; in the second one it is a different notice, but it agrees with $\mathrm{M} 1$ text. In the other three cases $(36,16$, 45,14 and 33,10), Lonzano's readings agree with the text of M1 and in the latter also with BA. The other two are BN readings.

Minhat $\breve{S}$ ay gives more information about the cases we are dealing with. It refers to 23 cases in Genesis and 3 in Exodus. It is surprising that only a few cases concerning hil lûffim are quoted in Exodus in both works, 'Ôr Tôrah and Minhat Śay. In 19 cases of Genesis, Norzi gives the two readings as in the margins of M1. The other four cases are: Gen 24,55 (הנערה), where Norzi gives the BA reading with ga 'ya' contrary to the note of M1; Gen 27,13 (קללתך), where Norzi gives the reading

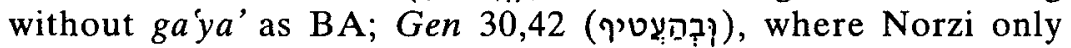
gives the BA reading with two géa yôt (in the 1 and in the 0 ); 
and Gen 45,14 (בנימין), where Norzi gives the first , with ga iya' as $\mathrm{BA}$, and the $\mathrm{D}$ with ga $y a^{\prime}$ as $\mathrm{BN}$.

In Exodus, the first case quoted by Norzi $(5,13)$ lacks in M1. The other two cases are 32,13 , and 38,26 , but the latter is erroneously given in $E x$ 38,1. In 32,13 , he gives a reading different from that of M1: he notes with ga' $y a^{\prime}$ 'as BA, contrary to the note in M1. He does not write anything about $\mathrm{BN}$ reading. In 38,26 , he gives $w$ w with merkah under the $n$ as $B A$ reading and with the accent under the $n$ as $B N$. In this case, he agrees with the note of M1.

In short, in most of the cases mentioned by Lonzano and Norzi, their opinions agree with the notes given in the margins of M1, specially in the cases where they refer to Spanish codices.

I have also compared the hil.lûfim of M1 with the list published by Ben Hayyim in his Rabbinic Bible. In Genesis, Ben Hayyim agrees with 16 cases where $\mathrm{M} 1$ has a BA/BN note in the appendix and in the margin of the text, and with 30 cases only quoted in the margin. The list of cases recorded in the margins is totally included in Ben Hayyim.

In 21 cases, Ben Hayyim's readings agree with BA/BN readings of $M 1$. In one case, Gen 6,7 concerning the word Ben Hayyim does not specify the difference. He vocalizes both readings identically. In eight cases, Ben Hayyim gives a reading different from that of $M 1$; sometimes he inverts the readings. This means that $B A$ reading in $M 1$ is $B N$ reading in Ben Hayyim. This is the case of (Gen 24,55). In M1 the $B A$ reading is without ga 'ya' under the $\mathrm{n}$, and in Ben Hayyim the BA reading is with ga' $y a^{\prime}$. Sometimes Ben Hayyim differs in the hîllluff itself, as in Gen 32,18, concerning the word

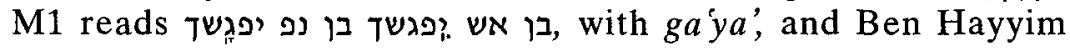
reads בן אש יפגזשך בן נפ יפגנשך, and marks the difference in the dages" or the rafeh.

In the other 16 cases, Ben Hayyim agrees with the hil.lufim of $\mathrm{M} 1$. In three cases, it gives a different reading and in two, its readings agree with Ben Uzziel's and are contrary to M1. For instance, in Gen 32,27, concerning the word raber in M1 the BA reading is $\dot{w}$, without $g a a^{\prime} a^{\prime}$, and in Ben Uzziel and in Ben Hayyim, the reading is with ga'ya' In general, in 32 of the 
46 passages, M1 agrees with Ben Hayyim. In only two cases, M1 gives a different reading from Ben Hayyim and Ben Uzziel, and they refer to the same word: reading and $₫$ without ga 'y $a^{\prime}$ as $\mathrm{BN}$ reading. Ben Uzziel gives the hil.laf inverted (BA without ga' $y a^{\prime}$ and $\mathrm{BN}$ with it). Ben Hayyim points the BA reading with the ga ya' under the s, and the $\mathrm{BN}$ reading with mûnah and without ga' $y a^{\prime}$ ' in the .

In Ben Hayyim's Bible, as well as in the mentioned cases of Lonzano and Norzi, the number of cases quoted in the book of Exodus are also few in comparison with those of Genesis. 16 of the 40. cases with a note in M1 are quoted in Ben Hayyim's list. In three passages, Ben Hayyim gives the hil lûff inverted. In Gen 32,13, he gives a different reading. Concerning the

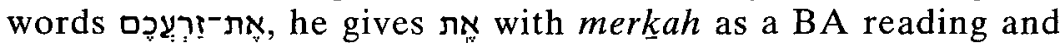
- $ת$ with maqqef as a $\mathrm{BN}$ reading.

\section{BA/BN READINGS}

Only in 15 of all the studied cases, M1 has a different reading from $\mathrm{BA}$ and $\mathrm{BN}$. In the rest of the cases, 40 are $\mathrm{BA}$ readings and 32 are $B N$ readings. In 12 occasions, the text of the manuscript has been corrected to convert it into $\mathrm{BN}$ in six

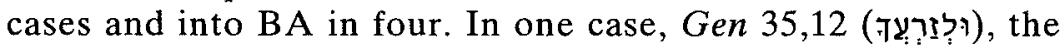
manuscript corrects the text to convert it into BA as specified in the M1 margin, but this is contrary to Ben Uzziel. In one

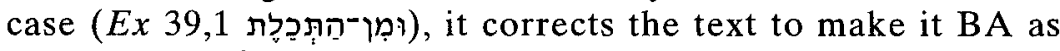
in Ben Uzziel's list. In conclusion, the manuscript has never a special reading without support. Only in one case (Gen 35,12$)$, the correction is to make it coherent with its own note.

As Dr. Fernández Tejero says in the study of the manuscript, this is a mixed text with special characteristics as all manuscripts. In some passages, the text has been corrected to adapt the reading sometimes to BA and sometimes to BN. M1 does not follow a certain school. It is important to remark that it has always support from other good manuscripts and sources, such as Norzi, Lonzano, and even Ben Hayyim. Norzi agrees with the M1 readings in 17 cases of Genesis and in three of Exodus. In some of them, he specifies that this is the correct reading of the Sifrê Sefarad. 


\section{THE APPENDIX TEXT}

As we can see in the tables, the text of the hillofifim in the appendix is not fully vocalized. Sometimes it is not vocalized at all, and sometimes it only gives some punctuation without specifying if it corresponds to a BA or a BN text. In many cases, it does not agree with the text of the manuscript. In the cases where the passage is also quoted in the margin of the text, the appendix text sometimes does not agree either with the text of the margin or with the text itself. Besides, the notes about the readings $\mathrm{BA} / \mathrm{BN}$ of the margins of the text are written by a hand different from that of the masorah of the manuscript, although the handwriting is very similar. In some cases, the handwriting is even very different, as in the explanation given in $E x 6,27$.

In my opinion, it is clear that each list corresponds to a different scribe and to a different source, even if they coincide in many cases. The main value of the appendix is that it gives more information, and sometimes, this information about the text differs from that of other manuscripts.

In the next pages, I offer the lists of passages studied. The abbreviations are as follows: TM1 = text of ms. $\mathrm{M} 1$; $\mathrm{MM} 1=$ Masorah Magna in ms. M1; AM1 = Appendix in ms. M1. 
Sef 57:2 (1998) SOME HIIL-LÛFÎM BEN ASHER/BEN NAFTALI IN THE MANUSCRIPT M1

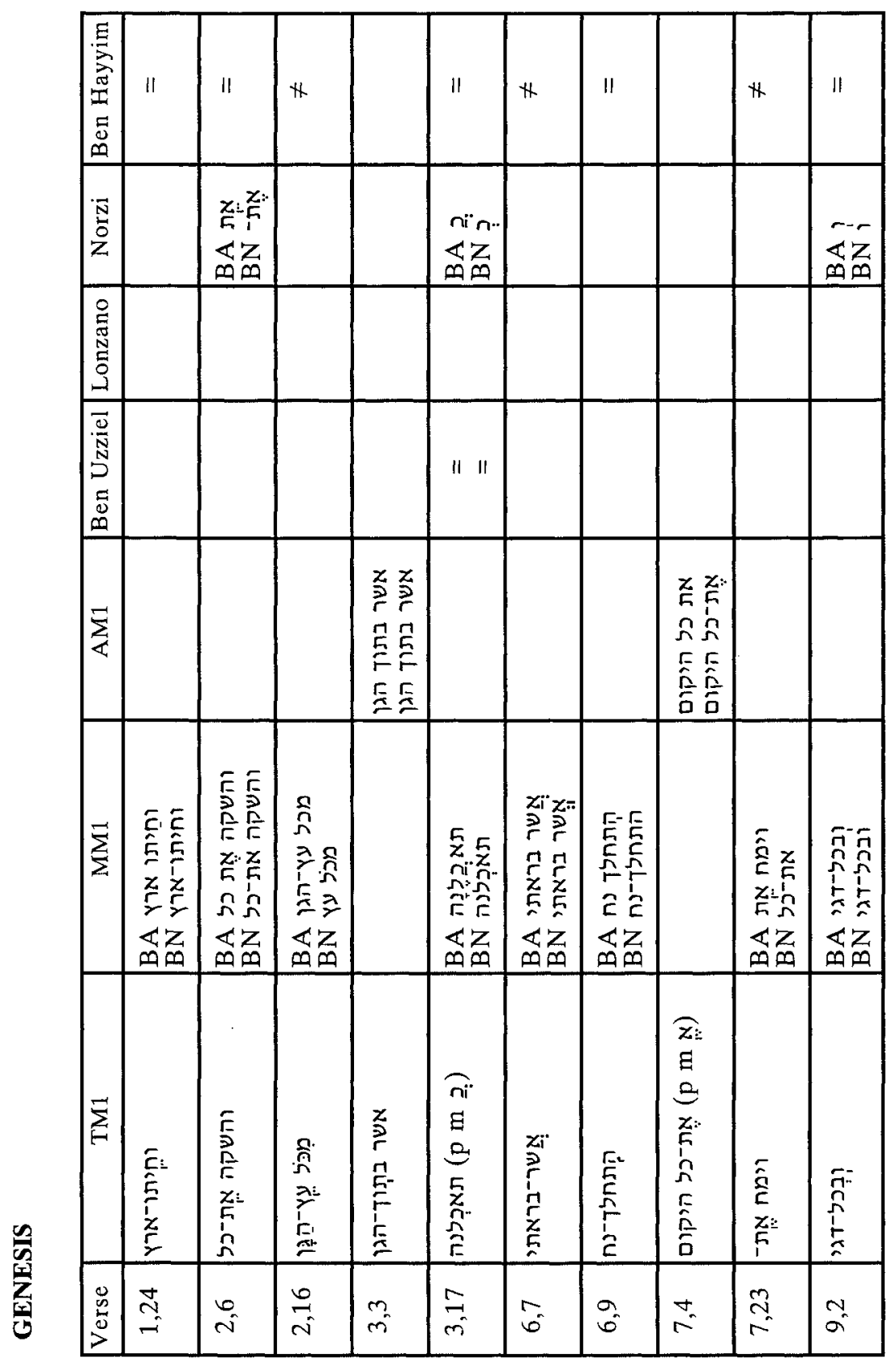




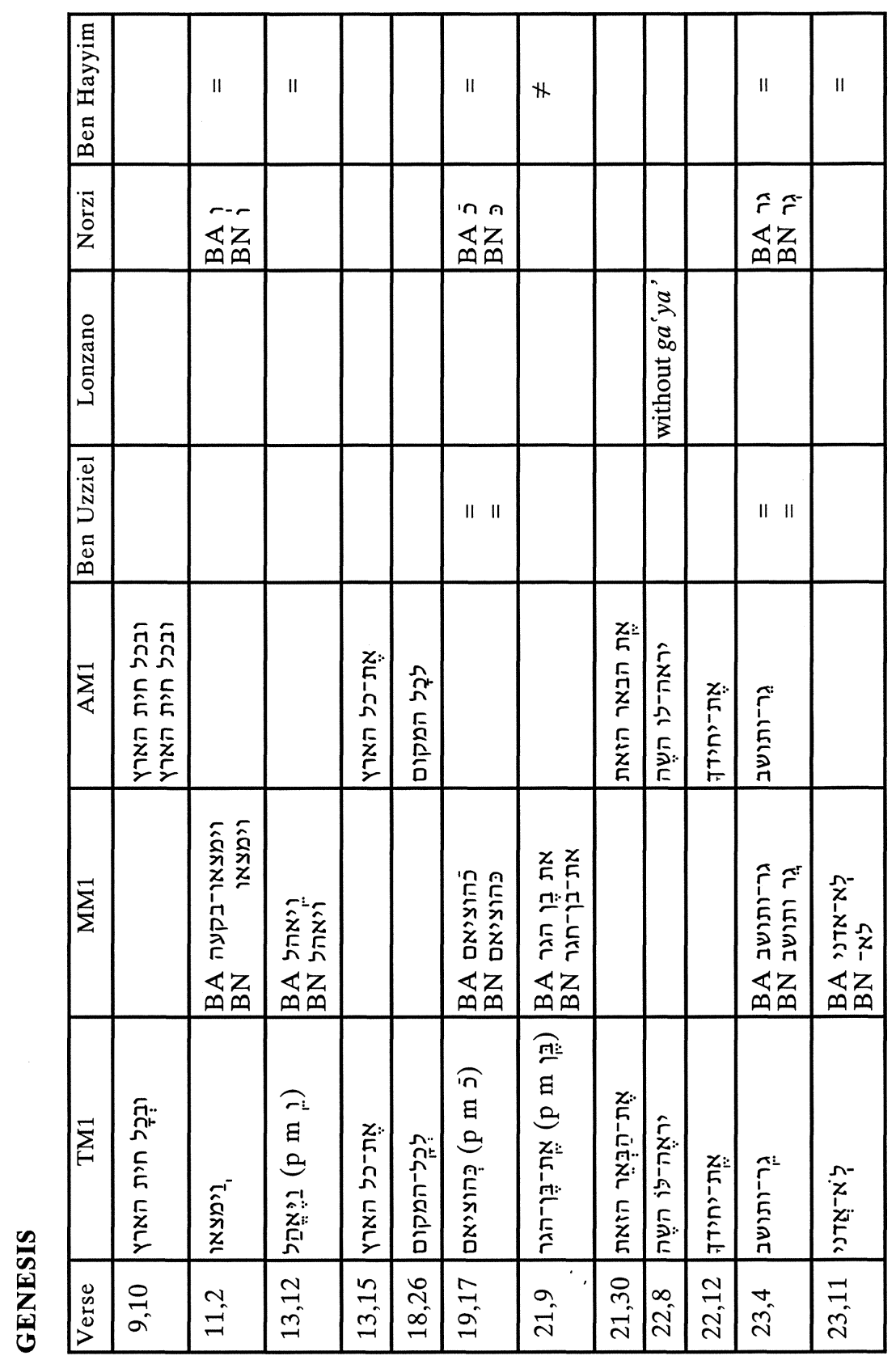




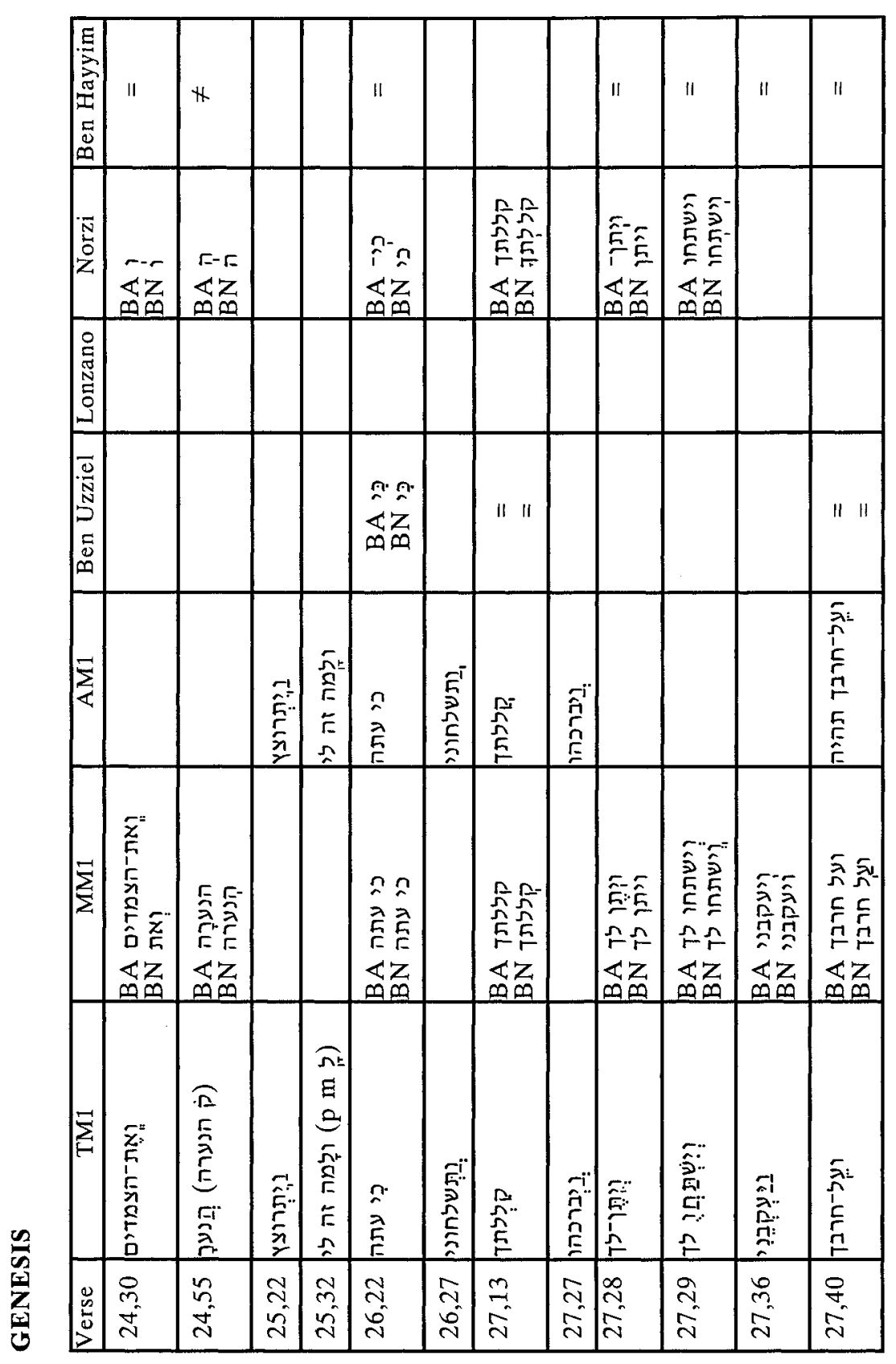




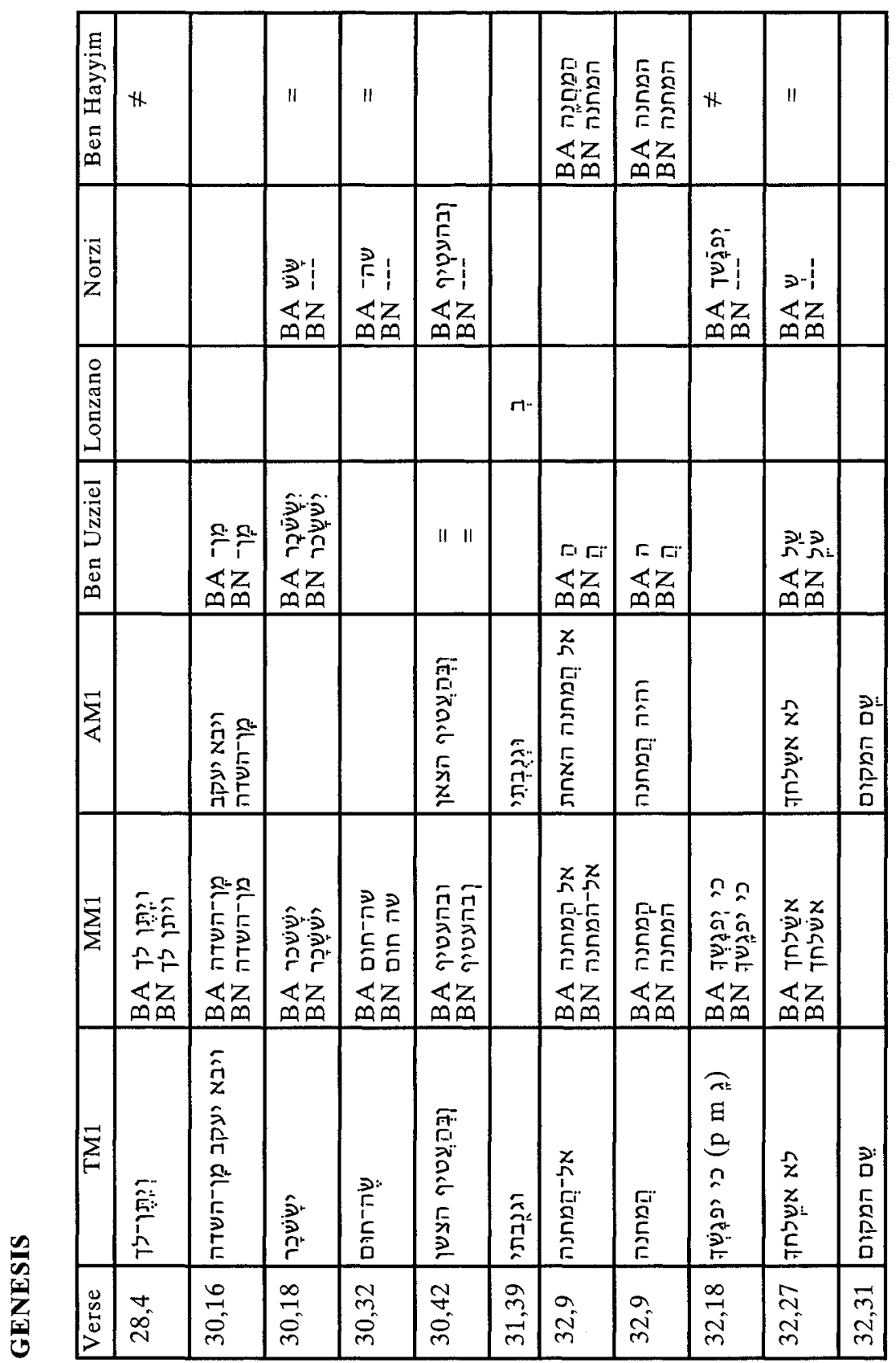




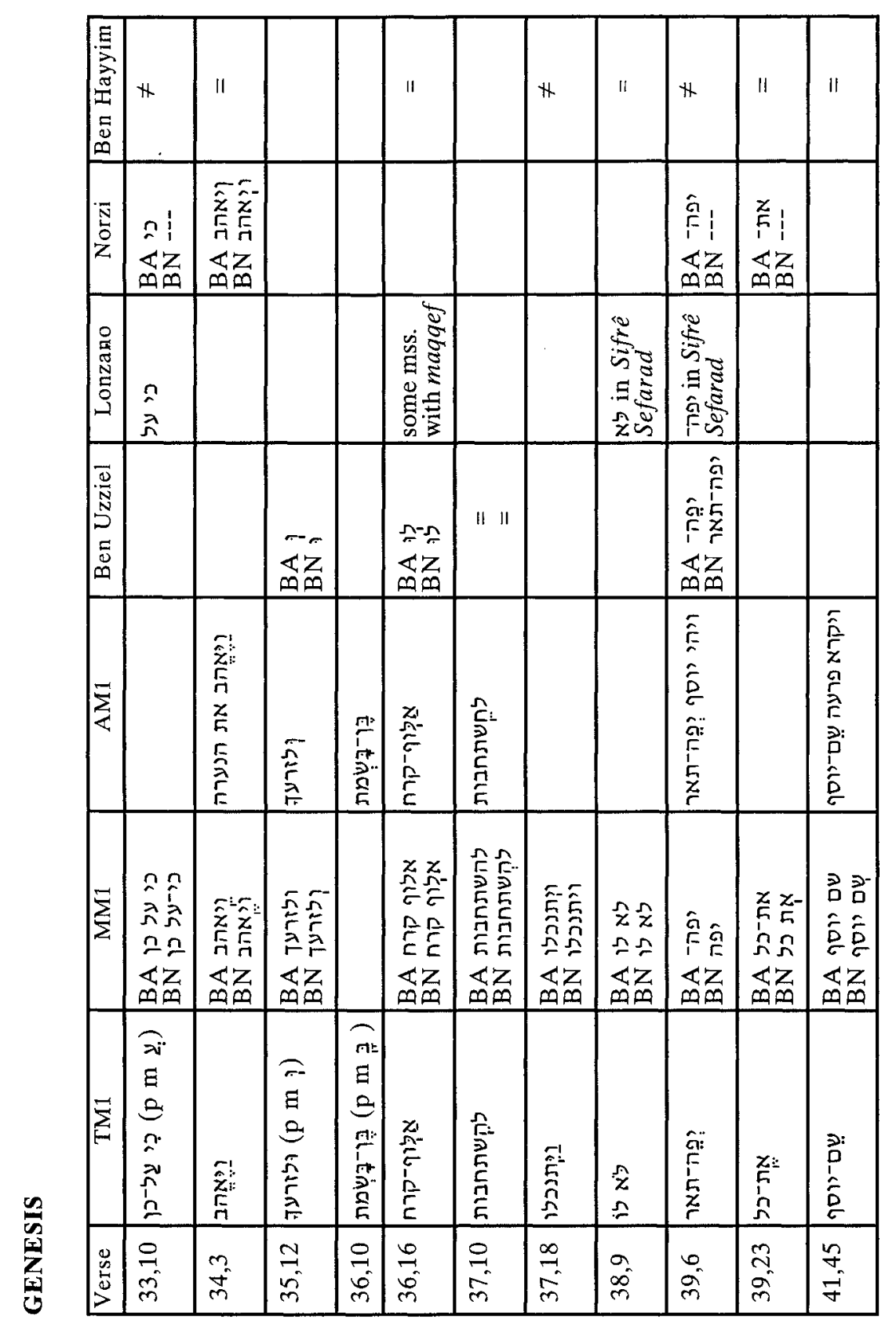




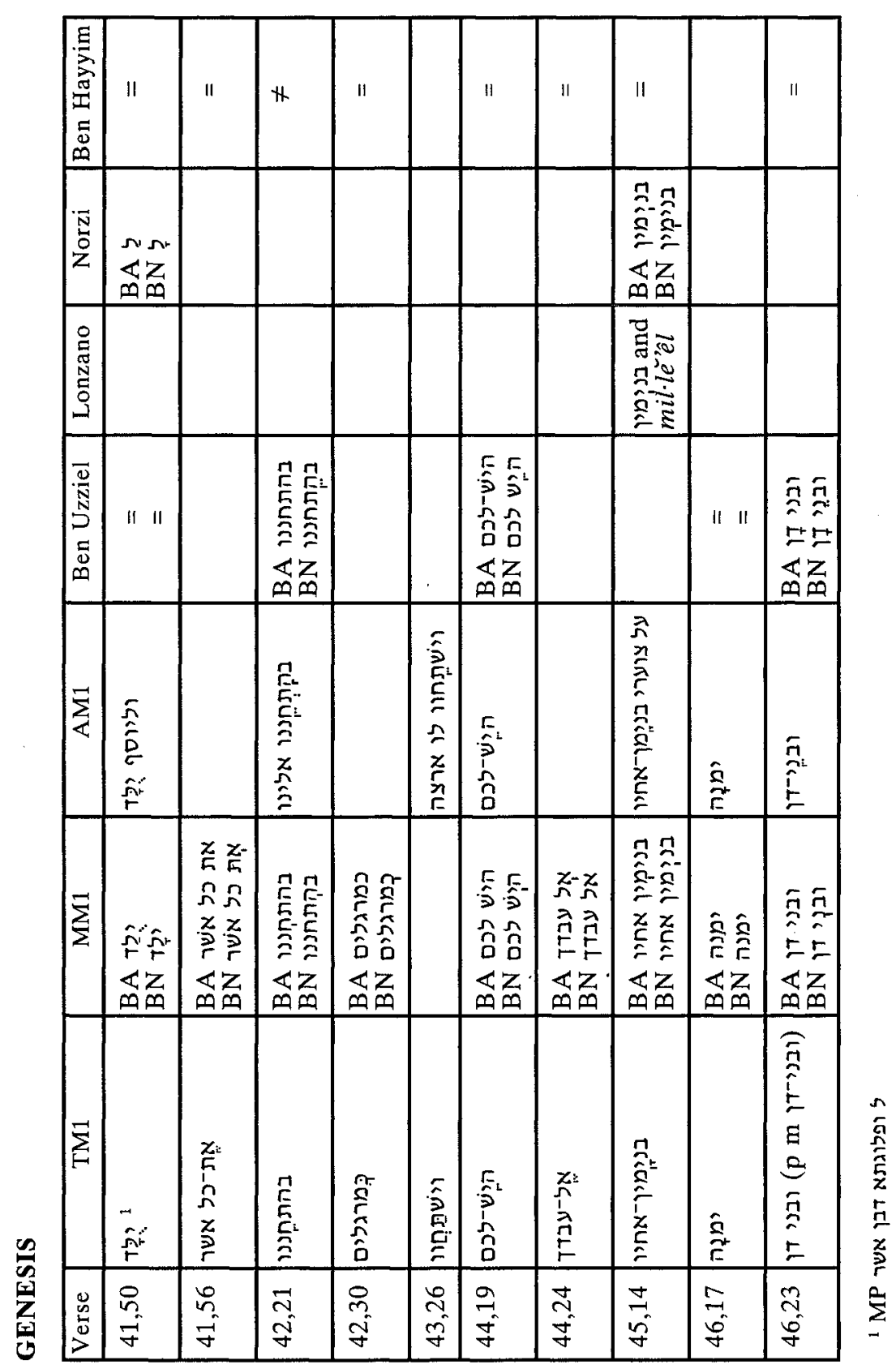



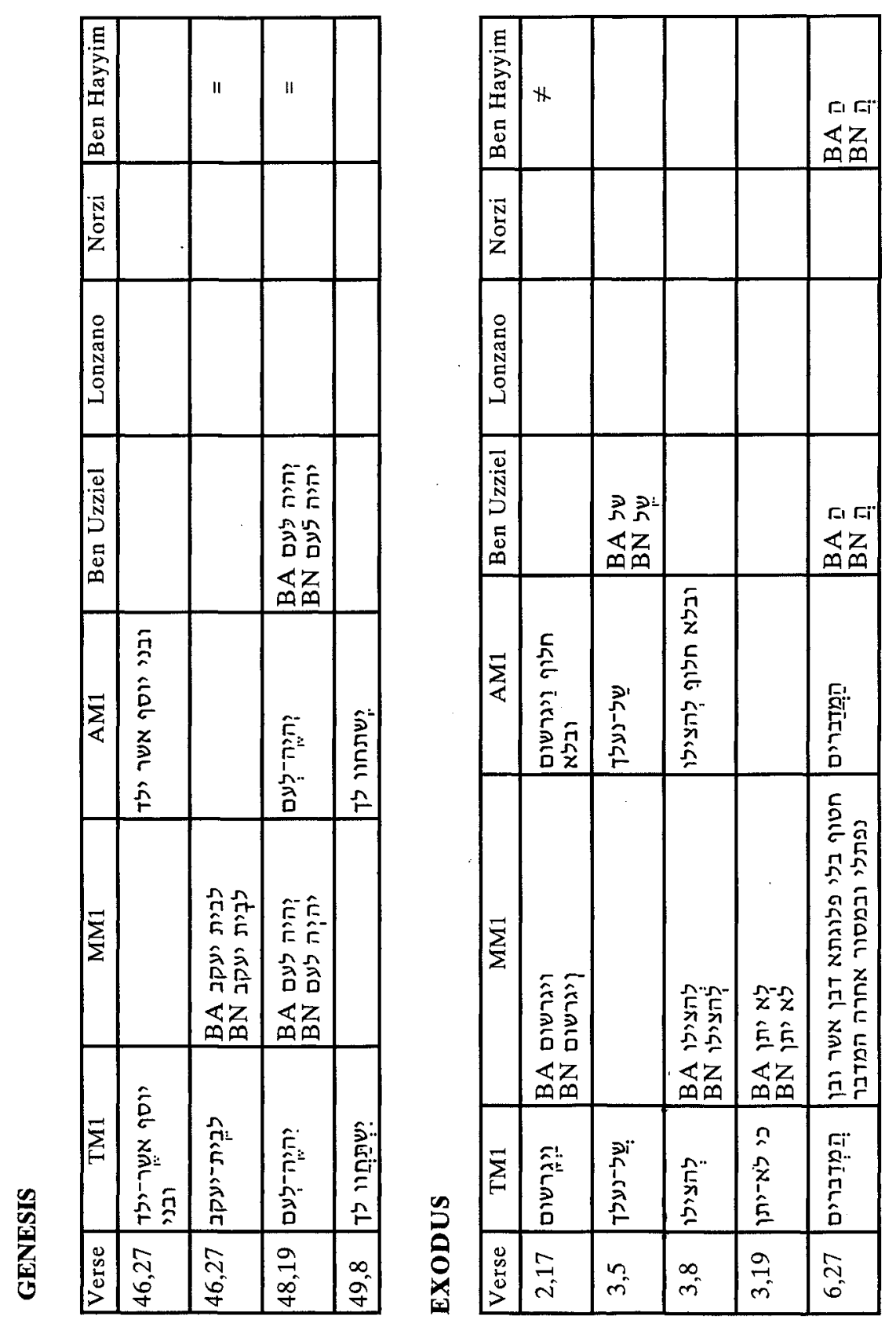


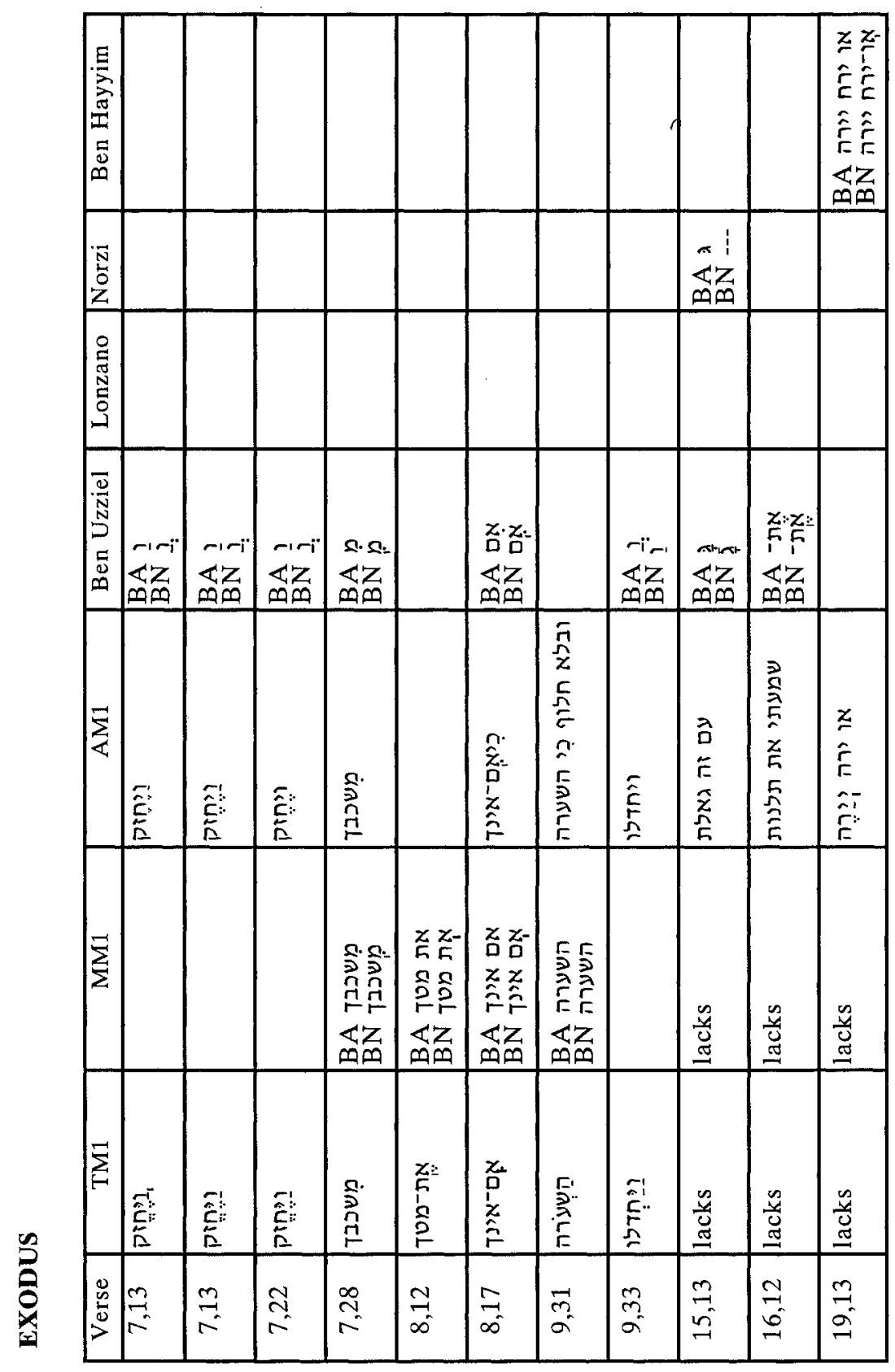




\begin{tabular}{|c|c|c|c|c|c|c|c|c|c|c|}
\hline 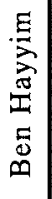 & & & & & $\|$ & & $"$ & & & $\|$ \\
\hline $\begin{array}{l}\bar{N} \\
\mathbf{C} \\
Z\end{array}$ & & & & & & & & & & \\
\hline 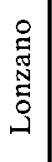 & & & & & & & & & & \\
\hline $\begin{array}{l}\bar{D} \\
\stackrel{N}{N} \\
D \\
5 \\
0 \\
\infty\end{array}$ & $\begin{array}{l}r i \\
i z \\
\infty\end{array}$ & 落 & & & & 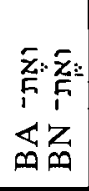 & & 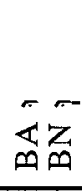 & & \\
\hline $\bar{\Sigma}$ & 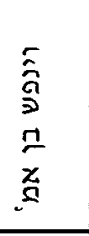 & $\hat{\hat{\hat{\hat{n}}}}^{:}$ & 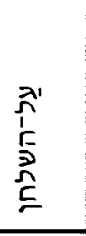 & 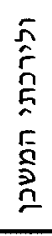 & & 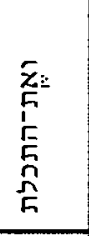 & & 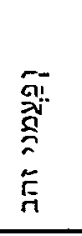 & & \\
\hline$\sum_{\Sigma}^{\bar{N}}$ & $\begin{array}{l}\tilde{\tilde{u}} \\
\stackrel{\tilde{\Xi}}{ت}\end{array}$ & 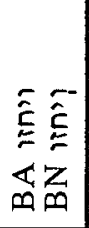 & 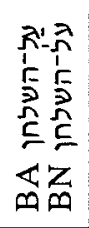 & & 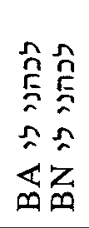 & & 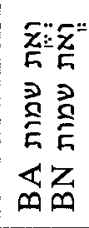 & & 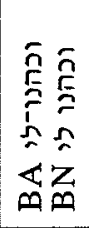 & 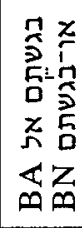 \\
\hline$\vec{\sum}$ & $\begin{array}{l}\tilde{y} \\
\tilde{d} \\
\tilde{g}\end{array}$ & 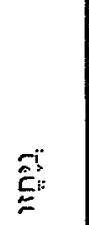 & 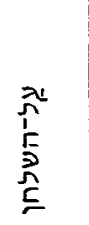 & 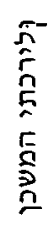 & $\begin{array}{l}\hat{n} \\
\hat{\sigma} \\
\hat{\hat{n}} \\
\hat{n}\end{array}$ & 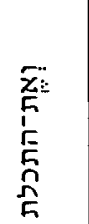 & 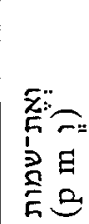 & 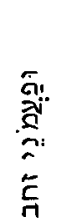 & $\begin{array}{l}\overline{\hat{n}} \\
\stackrel{5}{\sigma} \\
\hat{n}\end{array}$ & 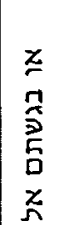 \\
\hline $\begin{array}{l}0 \\
\stackrel{0}{0} \\
\\
>\end{array}$ & $\frac{\sim}{\sim}$ & $\begin{array}{l}= \\
\stackrel{-}{\sim}\end{array}$ & 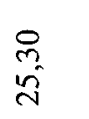 & $\begin{array}{l}\text { הి } \\
\text { ָे }\end{array}$ & $\vec{\infty}$ & $\begin{array}{l}n \\
\infty \\
\sim \\
\sim\end{array}$ & 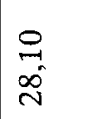 & 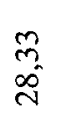 & $\begin{array}{l}\vec{y} \\
\infty \\
\text { in }\end{array}$ & $\begin{array}{l}\tilde{m} \\
\infty \\
\sim \\
\sim\end{array}$ \\
\hline
\end{tabular}




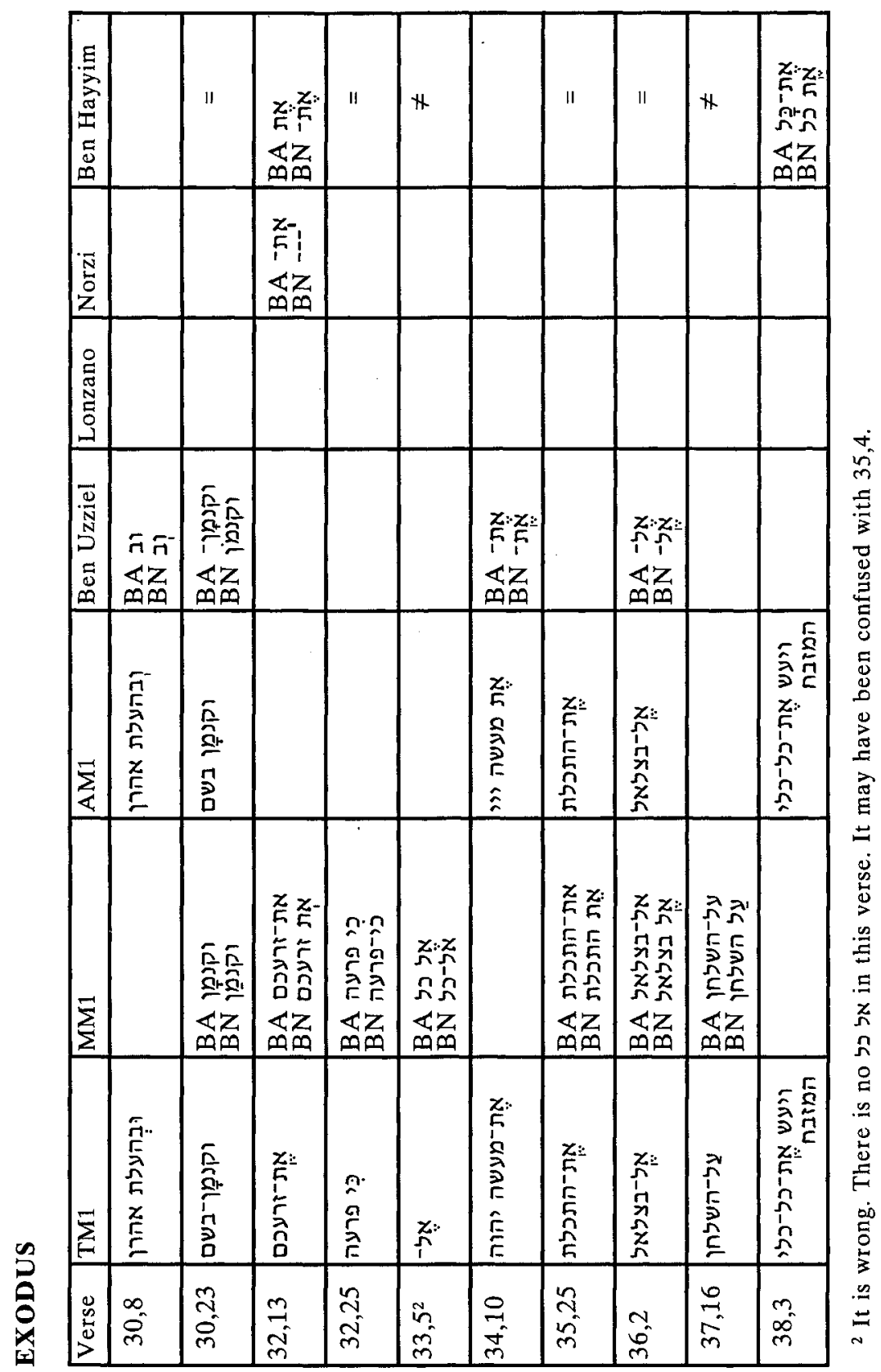




\begin{tabular}{|c|c|c|c|c|c|}
\hline 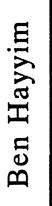 & & & $"$ & " & " \\
\hline $\begin{array}{l}\bar{N} \\
\text { Zे }\end{array}$ & 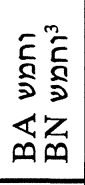 & & & & \\
\hline 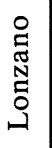 & & & & & \\
\hline 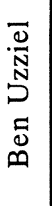 & & & 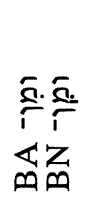 & $\begin{array}{l}\text { s. } \\
\ll z \\
m a\end{array}$ & 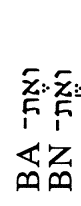 \\
\hline$\sum_{4}$ & & & & & \\
\hline$\sum_{\Sigma}^{J}$ & 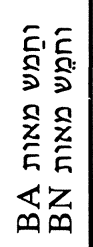 & 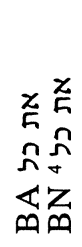 & 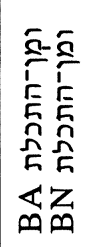 & 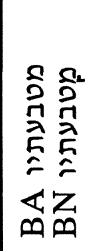 & 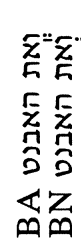 \\
\hline $\bar{\sum}$ & $\begin{array}{l}\tilde{E} \\
\hat{\Sigma} \\
\tilde{z} \\
\tilde{z} \\
\tilde{\hbar}\end{array}$ & $\begin{array}{l}\bar{Z} \\
\tilde{L} \\
\Omega\end{array}$ & 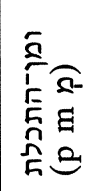 & 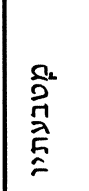 & 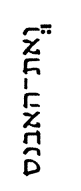 \\
\hline 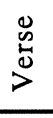 & $\begin{array}{l}\stackrel{0}{ } \\
\infty \\
\infty \\
m\end{array}$ & $\begin{array}{l}0 \\
m \\
\infty \\
m^{\infty}\end{array}$ & مे & $\begin{array}{l}\vec{N} \\
\text { ळे }\end{array}$ & $\begin{array}{l}\text { సે } \\
\text { ळे }\end{array}$ \\
\hline
\end{tabular}




\section{RESUMEN}

El manuscrito M1 (Biblioteca de la Universidad Complutense de Madrid) está siendo estudiado actualmente por el equipo de Biblia Hebrea del Instituto de Filología del CSIC en Madrid. Intentamos realizar la edición de la masora del Pentateuco en los próximos tres años. Al final del Pentateuco el manuscrito presenta cuatro páginas, escritas a tres columnas de cuarenta y dos líneas cada una. Este apéndice contiene, entre otras cosas, un recuento del total de paraśiyyôt Pentateuco, así como el número exacto de diferencias entre Ben Ašer y Ben Naftalí de cada libro. En el presente artículo se estudia la concordancia interna de esas diferencias con el texto y masoras del propio manuscrito en los libros de Génesis y Éxodo, y para tener una visión más amplia de la cuestión, en una segunda fase se comparan las listas de hillanfim con otros manuscritos tiberienses y con otras listas.

\section{SUMMARY}

The manuscript M1 (Madrid, Complutensian University Library) is being studied by the Hebrew Bible Team in the Instituto de Filología at the CSIC. We will be preparing the edition of the masorah of the Pentateuch in the next three years. This manuscript presents at the end of the Pentateuch four pages, written in three columns of fourty two lines each. This appendix contains, among other lists, a register giving the total sum of all the parasiyyôt, sedarim, verses, words and letters in each book of the Pentateuch, and the exact number of variations $\mathrm{BA} / \mathrm{BN}$ in each book. In this paper, $\mathrm{I}$ have studied the internal concordance of the variations $\mathrm{BA} / \mathrm{BN}$ with the manuscript in the books of Genesis and Exodus. As a second stage, I have compared the lists with the hilllufim recordered in other tiberian manuscripts, and with other hil.luffim lists, in order to have a broader scope of the subject. 